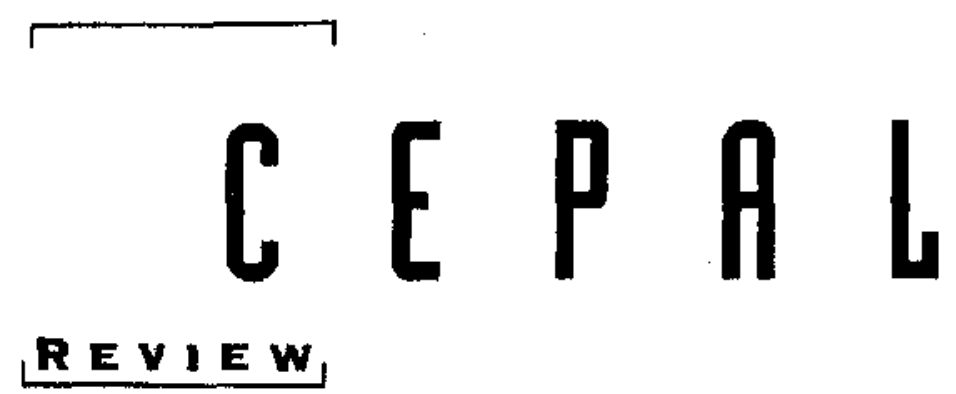

\author{
NUMEEF 65 \\ AUQUST 1998 \\ SANTIAGO, CHILE \\ O S CA ALTIMIA \\ Director of the Review \\ EUGENIO LAHEAA \\ Technical Secretary
}

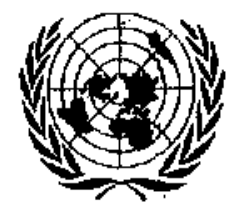


Income distribution, poverty and social expenditure In Latin Amerlca

José Antonio Ocampo

Military expenditure and development in Latin America

Eugenio Lahera and Marcelo Ortuzar

Growth, dlstrlbutive justice and social policy

Andrés Solimano

Equity, forelgn investment and International competitiveness

Adolfo Figueroo

Tensions in Latin American structural adjustment:

allocatlon versus distribution

Daniel M. Schydlowsky

Compethliveness and labour regulations

Luis Beccaria and Pedro Galín

Latin American femilles: convergences and divergences in models and pollcles

Irma Arriagada

Free trade agreements and female labour: the Chilean sltuation

Alicia Frohmann and Pilar Romaguera

Macroeconomic trends in Paraguay from 1989 to 1997:

consumptlon bubble and financial crisis

Stephane Straub

The strategies pursued by Mexican firms in their efforts

to become global players

Alejandra Salas-Porras

Pegulating the private provision of drinking water and sanitation services

Terence R. Lee and Andrei S. Jouraviev

Quallty management promotion to Improve competitiveness

Hessel Schuurman

Recent ECLAC publlcations 


\section{Equity, foreign investment and international competitiveness}

\section{Adolfo Figuero:}

Department of Economics. Catholic University of Perk, Lima.
Is the degree of competitiveness of countries independent of their degnee of inequality? Is competitiveness only a question of microeconomic and sectoral efficiency, of the real exchange rate, or is it also a social question? So far, the specialized literature has ignered the problem of squity in the determination of countries' competitiveness. It has then not been able to fully explain the observed competitiveness, however. In this article, equity is incorporated into the production function and also into investors' decisions in a world of perfect mobility of capital. The predictions of the proposed theoretical system are generally consistent with the data observed in the world economy. In particular, Latin American displays the highest degree of inequality of all the regions of the world, yet its share of foreign direct investment flows is low, and so is its share of word trade (its competitiveness). The theory presented here and the data assembled suggest that the relative levels of productivity of countries depend in a positive manner on the allocation of investments, and this allocation in tum depends, likewise in a positive manner, on the degree of equity prevailing in the countries. The competitiveness of a country therefore depends, among other factors, on its degreo of economic inequality. Societies compete in the capital market, seking to atract private investment in order to make themselves competitive in the goods market, and this is influenced, among other factors, by their current degres of equity. 


\section{I}

\section{Introduction}

International competitiveness is a favorite topic in the recent economic literature. As Krotgman (1995) says, there seems to be a dangerous obsession with this question. It is believed that there is a relation between differences in productivity -the basis for competitiveness- and national standards of living: a relation which Krugman finds unacceptable from both the logical and the empirical point of view, since it means that a country's standard of living would depend on its own productivity (i.e., on its absolute productivity) rather than its relative productivity.

What can we say about the relation between competitiveness and equity? Can it be that equity also depends only on absolute productivity and is therefore independent of relative levels of productivity, that is to say, of competitiveness? Or is it the other way round: competitiveness depends upon the degree of equity of the society in question? There is abundant economic literature which analyses equity and competitiveness separately, but there are very few studies on the interrelations between them. This article seeks to make some progress in this field.

The productivity of a country is an important factor in its competitiveness on international markets. What is the relation between productivity and equity, bowever? In order to answer this question, which is central to the present study, a theory of production is developed here in which equity is a variable of the production function (section II); the logic followed by investors with regard to country risk is analysed (section III); empirical tests are made of the predictions of the theoretical system (section IV); the role of the natural resources endowment is analysed (section V); and finally, some conclusions are put forward and the prospects opened up by the equity-competitiveness relation are summarized (section VI).

\section{II}

\section{Equity and productivity}

The competitiveness of a country may be defined as its capacity to win positions in the different international markets. The theory is that in the long term this capacity depends on the relative productivity of the country. But what are the factors that determine a country's productivity? A number of theoretical hypotheses may be suggested here in this respect.

$\square$ This study was initiated in the Regional Office of the International Labour Organisation (ILO) in Lima towards the end of 1995, in response to an invitation by Vfetor Tokman. A number of colleagues have offered valuable comments on its successive versions. Thanks are due in this respect to David Drukker, Javier Iguifíz, Ricardo Infante, Félix Jimenez, Jose Oseátegui and John Sheehan, and in particular to Oscar Altimir. I should also like to express my thanks to the panel of commentalors at the Latin American Studies Association (LASA) meeting at Guadalajara, 17-19 April 1997, at which this study was presented for the first time. It goes without saying that any exrors are entirely the responsibility of the author.
First, productivity depends on the entire system of production. As may be deduced from Leontief's technological system, the productivity of one sector cannot be independent of the productivity of the other sectors. The road infrastructure, transport services, ports and communications services are factors which also influence the productivity of the system of production. This has been acknowledged in a number of studies carried out in Latin America. Thus, the ECLAC study on changing production patterns with social equity (ECLAC, 1990) considers that productivity is a systemic matter. Indeed, if it is considered that there are interrelations between the sectors in a system of production -like those in Leontief's technological system- this conclusion is beyond question, Even the concept of "factor intensity" must be defined in relation to the total content (direct and indirect) of capital and labour per unit of 
product, and not just in relation to the direct coefficients, as is usually done.

Second, the productivity of the economy will depend not only on the intensity of the factors of production, but also on the changes in the quality of those factors and in technological knowledge.

Third, productivity also depends on the quality of the entrepreneurs. This is perhaps the most significant limiting factor. What are needed are entrepreneurs who continually review their methods of production and adopt the new technological developments generated outside the firm, as well as new products. But there is also a need, and indeed a pressing need, for "Schumpeterian entrepreneurs" who develop new methods of production with new practices and inputs, new products, new markets and new sources of inputs. And as the institutional framework within which firms operate is also important for efficiency, Schumpeterian entrepreneurs are also needed in the public sector in order to generate institutional innovations to allow the production system to raise its level of productivity.

The factors mentioned so far have already been dealt with in the economic literature. In this study, however, a new theoretical proposition will be introduced: that productivity depends on investment, and investment depends on social and political stability, which, in turn, depends on the degree of equity reached by society. The challenge, then, is to bring equity into the production function and subsequently prove this theory empirically.

In order to initiate our argument, we will postulate a production function of the following form:

$$
Q_{t}=f\left(L_{t} ; S_{1-F}, Z_{t-1}\right)
$$

Where $Q_{r}$ is the amount of a good praduced in the period $t, L$ is the number of workers used in the same period, $S$ is a vector representing the stock of private factors of production -land, physical capital and human capital (abour of different levels of skills)and $Z$ is a vector representing the stock of public factors of production, with both types of stocks being measured at the end of the preceding period.

We thus bring "public goods" into the production function. This set of goods includes not only infrastructure and public domain know-how (i.e., know-how that can be appropriated) but also social order. It is assumed that social order is a public good: once it is present, nobody can be excluded from its benefits. Social order is brought into the production function because without social order the production process cannot be repeated time after time, using the same amount of inputs for the same amount of product.

These stocks are accumulated through private investment and public investment. We will assume that such investments require one period in order to accumulate the corresponding stocks, so they are shown with a lag of one period in the production function. We will also assume that private and public investments incorporate technological innovations and give rise to the accumulation of both old and new production goods. It is therefore not possible to add vectors from periods which are different by one number (and call the result "amount of capital"), since they include stocks of production goods (physical and human capital) which are heterogeneous and of changing qualities.

In view of the logical difficulties raised by the problem of adding capital in a dynamic economy, the production function could be expressed only in terms of the relation between the product and the number of workers: a relation which changes continually with investment. This is the formulation which we will use here.

If we accept the idea that the social order should form part of the production function, then what are the factors that determine the social order? In another study (Figueroa, 1993), the theory has been put forward that the social order depends essentially on the degree of equity in the distribution of wealth. The axiomatic proposition is that not all kinds of distribution of wealth are socially tolerated. Only a strict subset of the possible distributions of wealth would be socially accepted; if the functioning of the economy led to a solution which lay outside these limits, society would enter into a distributive crisis, that is to say, into social disorder.

A distributive crisis depends not only on the distributive results of the market, but also on the redistributive policy of the State. Public social expenditure would be one of the mechanisms available to the State for reducing the distributive gaps arising from the functioning of the market and thus ensuring social order.

A growing impoverishment of the broad masses of the population (either absolute or relative) which brought society to a situation of distributive crisis would give rise to new forms of redistribution in 
which the rights of ownership were no longer fully respected. In such a situation, non-contractual income would take on increasing importance. As a result, there would be an increase in the levels of violence, corruption and uncertainty in the system of production. All this would entail economic costs for society. In the short term, there would be an increase in the cost of personal security and protection of property and in the costs due to stoppages on account of strikes and all kinds of social disorders. These costs would be passed on to the production costs of firms. Part of the social costs would thus be transformed into higher unit costs for the latter, with a consequent loss of competitiveness.

In the long term, the economic costs of a distributive crisis would include a retraction in private investment (to which we shall refer later on) and also a decline in the quality of labour. With the pauperization of the masses, for example, infant malnutrition increases, and it is well known that the learning capacity of human beings is largely determined in their early infancy, so that the quality of tomorrow's labour force is actually being determined today. It will therefore be much more costly to raise the productivity of workers who did not receive proper care in their infancy. The rates of grade repetition and morbidity would be higher, and as a result the investment in education and health needed to obtain a particular type of labour force would also be higher.

In short, our theoretical proposition is that productivity depends, among other factors, on the stability of society, which depends in turn on the degree of economic equity existing in society: if the degree of equity goes down, there will be a greater risk of sinking into social and political instability and the system of production will display lower productivity. Equity $(E)$ is an element in the production function of the various kinds of goods.

In the short term, with given stocks of private and public goods and a given level of technological knowledge, the production function may be written as follows:

$$
\begin{aligned}
& Q_{t}=n F(L) \\
& \text { where } n=n(E) \text { and where } \\
& n=1 \text { if } E \geq E^{*} \\
& 0<n<I \text { if } E<E^{*}
\end{aligned}
$$

There is a distributive crisis when equity $(E)$ has a value below the threshold of social tolerance of inequality $\left(E^{*}\right)$. In this case, enterprises would have to use resources to protect private property and also to reduce their transaction costs (understood as the higher risks associated with labour interchange, that is to say, greater mistnust in labour relations), which will have risen. In a situation of distributive crisis, labour productivity would fall and the curve describing function $F$ of equation (2) would shift downward. ${ }^{1}$

In the long term, the production function can be expressed as follows:

$$
Q_{t}=m_{t} F\left(L_{\mathrm{p}}\right)
$$

where $m>1$.

Let us assume that the function $F$ can only move upward, in accordance with the value of the variable $m$. Labour productivity would thus depend on the values assumed by the variable $m$.

What are the factors that determine $m$ ? We propose the hypothesis that the variables that move the function $F$ are private investment $(l)$ and public investment $(G)$, since these are the factors that expand the stock of private and public factors of production. Let us assume that the new technological know-how obtained through investment is incorporated both in physical capital and in human capital. We then have:

$$
m_{i}=\phi\left(\mathrm{I}_{b-1}, G_{i \cdot j}\right)
$$

We will assume that public investment is determined exogenously, but private investment will be considered endogenous. From the relations presented so far, it may be seen that in the long term labour productivity depends on investment, since this shifts function $F$ continually upward.

\footnotetext{
l By replacing equity with real wages, we can express in a more analytical manner what has been termed the theory of "efficiency wages" (Solow, 1990). If real wages were to fall below a certain threshold lovel, labour prochuctivity would fall. According to this theory, labour productivity depends on the level of real wages (and not the reverse, as conventional microeconomic theory maintains).
} 


\section{III}

\section{The logic followed by Investors}

What are the factors that determine long-term private investment in a country, however? We need a theory of investment.

There are as many as three different theories on long-term private investment: the first one holds that investment is endogenous to the economic process; the second, that it is endogenous to both the economic and socio-political processes, and the third, that it is totally exogenous. In the first case, the theory holds that private investment depends on the expected interest rates and yields, which depend only on expected relative prices (Barro, 1990). The second theory brings in the assumption that the expected yields also depend on the degree of stability of the socio-political system (Alesina and Perotti, 1993; Figueroa, 1993). In the third theory, investors would only be guided by their "animal spirits", as Keynes put it.

In this article, we will adopt the second theory. We will assume that investment decisions depend not only on the economic process but also on the sociopolitical process of society, that is to say, on the social order. Adopting the third theory would mean assuming that economic growth depends only on the state of mind of capitalists, so that there would be nothing to be done in terms of economic policy.

We will take it, then, that in the light of the risks facing an investor, his investment decision would depend on the expected yield and his capacity for absorbing risks. The greater that capacity is, the greater will be the tendency for the investor to enter into games which offer higher expected returns, although the risks are higher too. We will assume that this capacity is limited by the amount of assets that the investor possesses; that is to say, that aversion to risk is part of his restrictions and not of his preferences. Thus, investors with more assets would take greater risks (Figueroa, 1993).

We will also assume that capital is mobile among countries. In this case, how do investors decide which countries to allocate their funds to? In order to answer this question, we present an oversinplified model here. We shall consider two types of risks: product risk and country risk, since the investor must decide in what products and in which country to invest. In both cases, the investor faces two possible situations. In the case of the product, he can obtain either a good return $\left(r_{l}\right)$ or a bad return $\left(r_{2}\right)$. The expected return on his investment would thus be:

$$
r=P_{1} r_{1}+P_{2} r_{2} P_{1}+P_{2}=1, r_{1}>r_{2}>0
$$

where $P_{1}$ and $P_{2}$ can be interpreted as the probabilities that one or the other of these situations will take place.

Let us assume that the private and public production factors are complementary. Consequently, for given values of probabilities, the expected returns will depend on public investment $(G)$.

In the decision regarding the country, we will also assume two situations: in country $j$ there may be either socio-political stability or a situation of instability and chaos. We will term these probabilities $V_{1}$ and $V_{2}$ respectively, where $V_{1}+V_{2}=1$. Let us assume that if the first situation prevails, the investor obtains $r^{*}$, but if the second one occurs his retum will be zero. Consequently, his expected return, taking into account the country risk effect, would be:

$$
R_{j}=V_{I j}
$$

In terms of the expected return, the investor would invest in the country with the highest value of $R_{j}^{e}$, that is to say, in the country with the greatest socio-political stability.

In the previous model, the expected rate of return for the product was independent of the country. If we relax this assumption, then the return in country $j$ would be:

$$
R_{j}=V_{u j} r_{j}
$$

The investor would still invest in the country with the bighest value of $R_{j}$, but now it could happen that a country with relative instability (a low value of $V_{1}$ ) could nevertheless attract investments because the value of $r^{2}$ is relatively high.

In both models the risk is the same: loss of the whole investment if socio-political instability takes 
place. In other words, the risk consists of the country risk factor. If the investor had the capacity to absorb this possible loss, he would make his investment in the country with the highest value of $R^{e}$. If he did not have that capacity, he would not invest in any country at all.

If we introduce into this system of relations the theoretical proposition that the probability of having socio-political stability -that is to say, social orderdepends on the degree of equity, this means that the return on investment $R^{e}$ would not be independent of the degree of equity of society. Hence, as well as depending on public investment, private investment would also depend on the degree of equity of the society $(E)$ : that is to say, the investment function would assume the following form:

$$
\begin{aligned}
I & =H(G) \quad \text { if } E \geq E^{*} \\
& =J(G, E) \text { if } E<E^{*}
\end{aligned}
$$

where $E^{*}$ is the threshold of socially tolerated equity.

Private investment could not be independent of the degree of equity existing in the society. If the degree of equity were above the social tolerance threshold, investment would not be affected by changes in equity, but if it fell below that threshold or were in danger of falling below it, investment would go down. The assumption that investors have different capacities to absorb losses -different "disaster points", as Hicks (1989) would say- is enough to generate a curve where the relation between investment and equity is positive up to $E^{*}$. The lower the degree of equity (and of social stability), the higher the risk for the return on investment, so that only big investors with capacity to absorb possible losses would invest. As $E$ increases, the risk would go down and investors with less capacity to absorb losses would enter the market. Obviously, beyond $E^{*}$ the curve flattens out. ${ }^{2}$

Consequently, in a very unequal society the system of equations (3), (4) and (8) gives a production function with the following form:

$$
Q_{t}=f\left(L_{p} G_{t-j}, E_{t-1}\right), \text { where } E<E^{*}
$$

\footnotetext{
${ }^{2}$ It might be supposed that after reaching a high degree of equity the curve would take a downward direction, since an excess of equity can give rise to disincentives for investors. The curve would then have the form of an inverted $U$.
}

The level of production depends on the number of workers employed in the same period and also on public investment and the level of equity (when this is below the social tolerance threshold), both variables from the preceding period. We can thus say that a production process may be more or less "equity intensive" compared with another, depending on the degree of social stability acceptable to private investment. The latter depends on how many linkages this production process has with the other sectors of the economy. The more linkages it has, the greater its need for social stability, and hence the more equityintensive it will be.

Investors would seek to exploit the absolute advantages, comparative advantages or competitive advantages of the selected country. ${ }^{3}$ The logic behind their decisions would be guided by the model developed here. But their investments would help to develop those advantages for the future, which would give rise to a dynamic effect. When the production process for a good is less intensive in terms of social stability, the investment may be less sensitive to country risk, and investors could seek to produce that good in enclaves (mines, oilfields, in-bond assembly activities, tourism centres). But if the production process in question is intensive in terms of social stability, the country risk may have a very substantial effect, so that they would not invest in the good in question. Because of the country risk factor, under which lies the degree of equity, the competitive advantages of a country might not be developed and its comparative advantages might not evolve.

In this theoretical formulation, equity results from the functioning of the market in the preceding period (which naturally operates with exogenous variables) and the social policies of the government, which is also an exogenous variable. But the theory we want to put forward here is that in a society whose development process starts from an initial condition of marked inequality, this inequality will be maintained. The market will not be able to reduce it, the political system will have no incentives to do so, and the situation of inequality will tend to persist. There will thus be a state of pronounced inequality in that society.

\footnotetext{
${ }^{3}$ In line with Krugman, we will understand competitive advantages as being those which affect intra-industry trade.
} 
A prediction with empirical content can be derived from this theoretical system: societies with a high degree of inequality will receive little foreign direct investment; other conditions being equal, a country with greater equity would attract a larger proportion of private investment, thereby raising its productivity and improving its share in

\section{IV}

\section{Empirical data}

A new set of data on equity presented recently by the World Bank (Deininger and Squire, 1996) is based on a sample of 108 countries from the $1950 \mathrm{~s}$ to the 1990 s, with a total of 682 observations. In this sample, Latin America (with 20 countries and 100 observations) appears as the region with the greatest inequality in the whole world (table 1), Its Gini coefficient has an average level of 0.50 , while that of the advanced capitalist countries is 0.33 and that of the Asian "Tigers" is around 0.35. This order is maintained if the index used is the ratio of the shares in total income of the top and bottom quintiles.

In reality, there are two other interesting results which emerge from the data of Deininger and Squire (1996, table 1): first, the order of inequality among the regions is maintained over time; and second, the changes in the Gini coefficients are not radi- the international market. Another empirical prediction which can be derived from this theory is that in very unstable economies transnational corporations (whose capacity to absorb risks is greater than that of domestic firms) will have a bigger share in total private investment. Both predictions are empirically verifiable. cal within each region. ${ }^{4}$ These data are consistent with our hypothesis of the persistence of pronounced inequality when this is an initial condition of the economy.

\footnotetext{
1 Even at the country level, there is noteworthy stability of the Gini coefficient: for the countries with more than 10 observations, the Pearson variability coefficient does not exceed $12 \%$. This empirical fact rases some interesting questions: for example, is equity a structural characteristic of each society: an initial condition which it is hard to modify substantially?

5 The famous scientist Alexander Humbold wrote that one of the features which impressed him most in his visits to the Americas was the tremendous economic and social inequality. A hundred and fifty years later, we are still talking about this same feature as one of the central problems of Latin America.
}

Indexes of inequality, by regions, 1947-1996

(Averages)

\begin{tabular}{lccc}
\hline & $\begin{array}{c}\text { Number of } \\
\text { observations } \\
\text { (countries per year) }\end{array}$ & Gini coefficient & $\begin{array}{c}\text { Ratio of the shares } \\
\text { of the top and bottom } \\
\text { deciles in total income }\end{array}$ \\
\hline Latin America & 100 & 0.50 & 16.02 \\
Africa south of the Sahara & 40 & 0.45 & 11.61 \\
Middle East and North Africa & 20 & 0.41 & 7.14 \\
East Asia and Pacific & 123 & 0.36 & 7.15 \\
South Asia & 60 & 0.34 & 5.50 \\
Industrialized countries & 238 & 0.33 & 6.63 \\
Eastern Europo & 101 & 0.26 & 4.05 \\
Total & $\mathbf{6 8 2}$ & $\mathbf{0 . 3 6}$ & $\mathbf{7 . 3 0}$ \\
\hline
\end{tabular}

Source: Deininger and Squire, 1996, table 1. 


\begin{tabular}{lcrr}
\hline & & Billions of dollars \\
\cline { 2 - 4 } & $1981-1985$ & $1986-1990$ & $1991-1993$ \\
\hline A. All countries & 50 & 155 & 171 \\
B. Developing countries & 13 & 25 & 57 \\
C. Latin America and the Caribbean & 6 & 8 & 17 \\
C/A (\%) & 46.2 & 32.0 & 30.0 \\
C/A (\%) & 12.0 & 5.2 & 9.9 \\
\hline
\end{tabular}

Source: ECLAC, 1995, table II.2, p. 53.

TABLE 3

Foreign direct investment flows to Peru and to a group of Latin Amerlcan countrles, ${ }^{\circ}$ 1988-198s (Millions of dollars)

\begin{tabular}{|c|c|c|c|c|c|c|}
\hline & 1988 & 1989 & 1990 & 1991 & 1992 & 1993 \\
\hline Peru & 26 & 59 & $4 I$ & -7 & 127 & 349 \\
\hline Normal FDI & 26 & 59 & 41 & -7 & -13 & 60 \\
\hline Debt conversion & - & - & - & - & - & - \\
\hline Ptivatization operations & - & - & - & $=$ & 140 & 289 \\
\hline Group of Latin American countries & 7961 & 7469 & 6951 & H 062 & 12271 & 44420 \\
\hline Normal FDI & 3613 & 4570 & 3894 & 7512 & 9826 & 8388 \\
\hline Debt conversion & 4154 & 2784 & 1841 & 305 & 133 & 25 \\
\hline Privatization operations & 194 & 115 & 1216 & 3245 & 2312 & 6007 \\
\hline Peru/Group (果) & 0.3 & 0.8 & 0.6 & $-0 . I$ & 1.0 & 2.42 \\
\hline
\end{tabular}

Source: ECLAC, 1995, table IX,4, p. 192.

"Comprising Argentina, Brazil, Chile, Colombia, Mexico, Peru and Venezuela.

Latin America's share in foreign direct investment flows has been going down since the first half of the 1980s, regardless of whether it is measured with respect to all countries or only the developing countries (table 2). Peru, which is one of the countries in the region where economic inequality is most pronounced, suffered from marked political instability in the period from 1988 to 1992 . In that period, foreign investment only entered the country in small amounts, beginning to increase only in 1993 (table 3). These data are in keeping with our hypothesis that a bigger share of investments goes to the more equalitarian societies.

The relation between equity and investment, which is a structural equation in our theoretical system (equation (8)), is statistically tested in a study by Alesina and Perotti (1993). For a sample of 70 countries, with data from the period 1960-1985, they find a negative correlation between equity and socio. political instability, on the one hand, and between socio-political instability and investment, on the other. The 16 Latin American countries included in this sample displayed the highest degrees of inequality and socio-political instability, as well as the lowest rates of investment (Alesina and Perotti, 1993, tables 4 and 5 and p. 19).

These authors' interpretation of their results, and the policy conclusions they draw from them, suffer from a logical difficulty, however. In their model, these authors take income distribution as an explanatory variable: that is to say, as an exogenous variable of the economic process, but there is no economic theory that endorses such an assumption. The best way of solving this logical difficulty would be to consider a theoretical system like that developed here, in which investment in the current period depends on the degree of socio-political instability in the same period, and in which this latter variable de- 


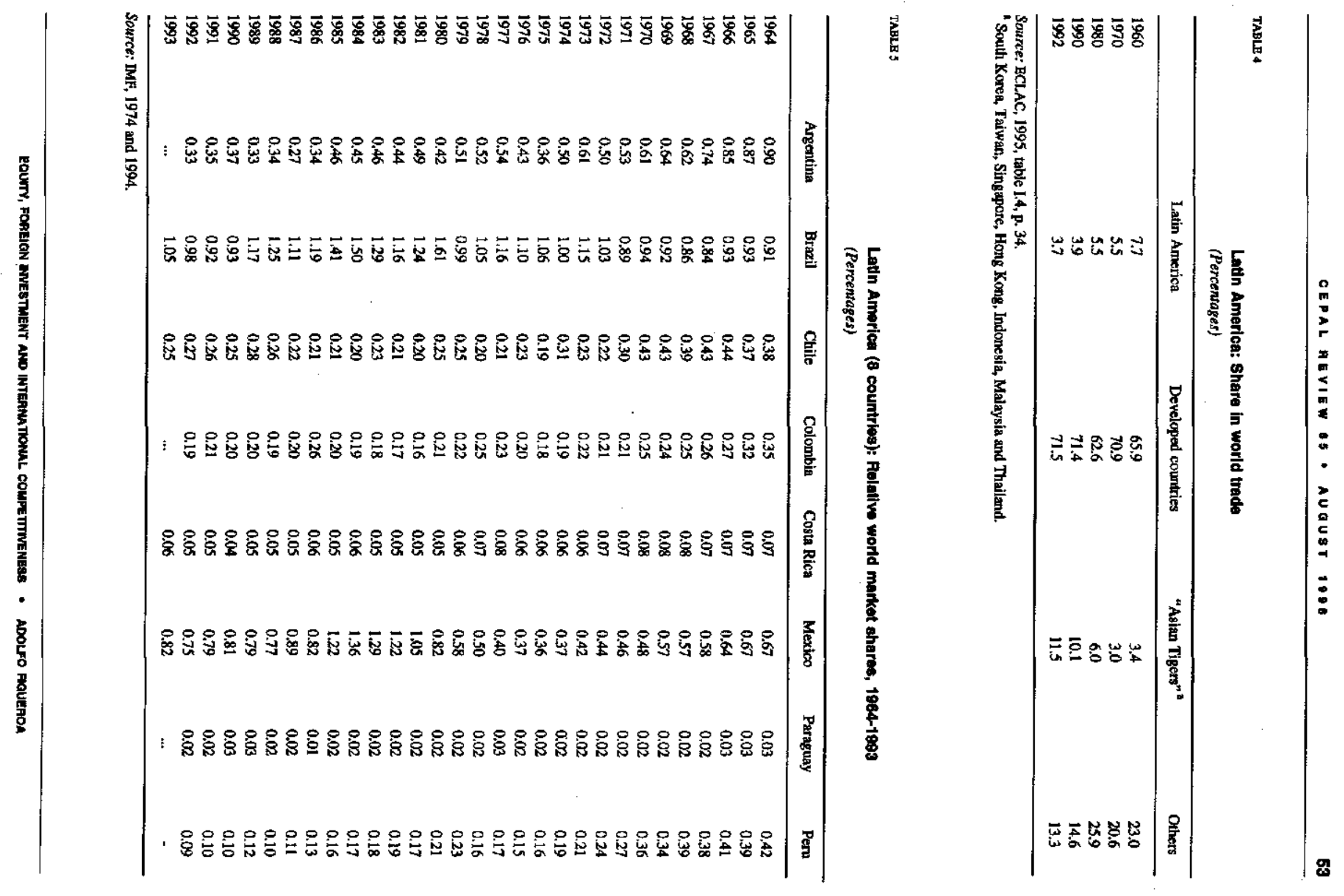


pends on the degree of equity in the preceding period. In this dynamic system, in the absence of data on the distribution of asset stocks, income distribution can be used as an initial condition in the timepaths of the endogenous variables.

Indeed, in the statistical analysis made by the above-named authors they use the income distribution at the beginning of the period studied (1960), while for the other variables they use the averages for the period 1960-1985. But in this case the interpretation of the results cannot be that which they do in fact make: that investment depends on the degree of inequality -"income inequality increases political instability, which in tum reduces investment" (Alesina and Perotti, 1993, p. 18), for both are endogenous variables. If these data are considered to be generated by a dynamic system, the causal relation would have to be different: that high income concentration, as an initial condition, increases the risk of socio-political instability, which leads to lower investment and growth rates.

Moreover, Alesina and Perotti's policy conclusions also need to be reformulated. They conclude that income redistribution has unpredictable net effects, since the higher tax pressure needed to secure such redistribution would reduce the incentives to invest. This effect may be one of levels and not of rates, however. This confusion is similar to that which exists when it is considered that international trade barriers based on protective tariffs, which are also tax rates, constitute a factor affecting economic growth. As Lucas (1988, pp. 12 and 13) rightly points out, the easing of such baniers could have an effect on the level but not on the rate of growth. If we adopt Lucas's theory that income distribution affects the growth rate, the logical conclusion of Alesina and Perotti's study, in the light of our reinterpretation of its empirical results, would have to be different: re- distributing income, as a change in the initial conditions, would give rise to a different path marked by higher investment and growth: in other words, it would affect the growth rate.

Judging by its share in world trade, Latin America has lost competitiveness since the 1960s. Table 4 illustrates this trend very clearly. Between 1960 and 1992 the region's share in trade fell by more thati half, from $7.7 \%$ to $3.7 \%$. The developed countries account for most of world trade and have increased their share still further. The group that has increased its competitiveness most markedly, however, is that of the so-called "Asian Tigers" (South Korea, Taiwan, Singapore, Hong Kong, Indonesia, Malaysia and Thailand).

A sample of eight Latin Americar countries reveals the same pattern as for the region as a whole: loss of participation in the world market, although with differences of degree which are worthy of note (table 5). The loss of market shares has been most serious in the cases of Argentina and Peru, but less severe in Colombia and Costa Rica. Chile lost part of its market share between 1964 and 1986 and subsequently began to recover somewhat, although it did not manage to recover its market level of the early $1960 \mathrm{~s}$ in the period studied. Paraguay has maintained its market share almost unchanged over the period, albeit with big fluctuations from year to year. Brazil registered successes during the period from 1964 to 1984, but since then it has lost ground and declined to levels similar to those of the early 1960s. The relatively most successful country is Mexico. It lost ground in 1964-1976, made substantial gains in 1977-1985, only to lose part of its advances between 1986 and 1989 , settling down since then at a level somewhat higher than that of the early $1960 \mathrm{~s}$. In short, the Latin American sample does not include any case comparable to that of the "Asian Tigers". 


\section{V}

\section{The role of resource endowment}

The importance of equity in determining private investment depends, as we already noted, on the degree of integration of the export sector in the national economy. Private investment will seek to exploit the absolute, relative or competitive advantages, according to the country's initial conditions as regards resource endowment and equity. A society which only has an ample endowment of natural resources, with a high degree of initial inequality, could only attract investments seeking to exploit its absolute advantages and some of its comparative advantages. With such investments, however, it would be hard for the country to emerge from its social backwardness.

A significant endowment of natural resources can be counterproductive. A country in such a position may find it difficult to develop on the basis of absolute advantages. The exploitation of a country's absolute advantages does not require that it should have socio-political stability. The export activities can take place in an enclave. The more integrated the export sector is in the productive system of the country, however, the more important social order, and hence equity, will be for attracting private investments to develop the export sectors.

Consequently, societies with a good endowment of natural resources will have a higher level of foreign investment, for a given degree of inequality in the society. This is another empirical prediction of the model.

What kind of goods has Latin America specialized in? Throughout almost its entire history, up to the late $1970 \mathrm{~s}$, the region has specialized mainly in primary commodities such as those produced by the mining, petroleum, fishery and agricultural sectors; only in recent decades has it developed exports of manufactures (table 6 ).

With primary commodities, the region is exporting its abundant natural resources endowment, including its climatic advartages. Its deposits of minerals and petroleum enable it to export those products, while thanks to its biodiversity it can export fishery products, coca, coffee, cotton, sugar, asparagus, llama wool: in other words, goods that cannot be produced just anywhere in the world or at just any time of year. Tourism also represents the export of a natural resource based on the climate or historical remains.

A combination of absolute and comparative advantages lies at the basis of this specialization. Except in the case of some agricultural products, however, the exploitation of these natural resources has not meant that the region exports goods making intensive use of labour, which is its relatively most abundant factor. Minerals, metals and fuels make relatively more intensive use of capital. Through them, Latin America is exporting goods with a high rate of return. Thus, a considerable part of its exports do not depend on variations in international prices, or the exchange rate, or wages, at least to a significant extent, but on investment.

Agricultural production, which makes relatively intensive use of labour (especially unskilled labour), has lost relative importance in the region's exports (table 6). In absolute terms, the data show that the volume of agricultural exports grew by $4 \%$ per year in the $1970 \mathrm{~s}$, but this rate went down to $2.3 \%$ in the 1980s (ECLAC, 1995, p. 70).

Although there has been an expansion in exports of manufactures throughout the region, the data in table 6 conceal marked differences between countries. Almost $75 \%$ of exports of manufactures in 1993 were accounted for by Brazil and Mexico alone (ECLAC, 1995, table III.5, p. 77). Without these countries, the simple average for the region is only $18 \%$ instead of the $39 \%$ shown in the table.

Within manufacturing activity, there is a traditional goods sector which is relatively labourintensive: textiles, clothing and footwear. In this sector, the relative abundance of labour seems to play an important role in competitiveness. The location of in-bond assembly activities for these products by transnational corporations in various countries of the region appears to be based precisely on the existence of cheap labour.

There are not sufficient data to prove the hypothesis that investments in primary sectors require less socio-political stability, but there is a story which serves to illustrate this hypothesis. Cusiana, in Colombia, is the biggest oil deposit found in Latin 
TABLE 6

Latin America and the Caribbsan: Export etructure

(Percentages)

\begin{tabular}{lrrrrr}
\hline & 1962 & 1970 & 1980 & 1990 & 1992 \\
\hline Agricultural products & 52.4 & 47.1 & 31.2 & 28.3 & 29.8 \\
Metals and mineralis & 13.1 & 18.2 & 10.4 & 11.7 & 9.7 \\
Fuels & 29.1 & 22.9 & 40.6 & 26.5 & 21.6 \\
Manufactures & 5.2 & 11.5 & 17.3 & 32.9 & 38.5 \\
Othors & 0.2 & 0.3 & 0.5 & 0.6 & 0.4 \\
Total & 100.0 & 100.0 & 109.0 & 100.0 & 100.0 \\
\hline
\end{tabular}

Source: ECLAC, 1995, table I.6, p. 39.

America in the last twenty years and involves an investment of US $\$ 6$ billion. The oil company in question, which was foreign, had to interrupt its prospecting work on a number of occasions because the guerrilla movements invaded and destroyed its installations, and soldiers have been stationed in Cusiana to drive the guerrilla out ( $E$ l Comercio, 1996, p. E6). This oilfield will be put into operation immediately, even though Colombia is a country plagued by poverty, political chaos, guerrilla activities and dope trafficking. It would appear that there are no prior requisites in terms of socio-political stability for exploiting oilfields: they operate as physical and economic enclaves.

The other hypothesis is that different factor endowments give rise to different patterns of trade and different degrees of distributive equity. More specifically, investments which develop an export sector based on the exploitation of natural resources are likely to lead to greater income concentration. This hypothesis was empirically tested by Bourguignon and Morrisson (1989, chapter $\mathrm{II}$ ) in a cross-sectional analysis for 1970. The sample included twenty developing countries, of which six were in Latin America (Argentina, Chile, Colombia, Costa Rica, Peru and Uruguay).

For its statistical analysis, the study by Bourguignon and Morrisson included income distribution as an endogenous variable (measured through the shares of selected deciles in national income), while the exogenous variables were the degree of trade protection, the weight of agricultural exports and exports of minerals and petroleum products in the gross domestic product, the structure of land ownership, and education. The results show that protection has a negative effect on equity, as also does specialization based on natural resources, except when agricultural exports come mainly from small farms. Trade patterns based on absolute advantages lead to concentra- tion of income, while those based on comparative advantages in agriculture depend on the degree of concentration of land ownership.

These results can be re-interpreted in the light of our theory: inequitable societies well endowed with natural resources will attract investments aimed mainly at exploiting their natural resources, so that they will continue to be inequitable and unstable. This mechanism leads to the maintenance of the initial condition of highly unequal societies.

From this theoretical standpoint, public social expenditure may be seen as a means of establishing minimum floor levels for the income and well-being of the population, thus giving stability to the social and political system. These actions may be termed "social policy". This floor level would have to be established as a set of rights, however: a redistribution of income to finance economic rights. This means that the goods and services in question would have to be withdrawn from the play of the market forces and political and electoral interests. Social stability, like democracy, is a public good: once it has been established, no-one can be excluded from its consumption. It is therefore clear that public social expenditure is a form of investment in a public good: social stability.

The Latin American experience has not moved in this direction, however. An ECLAC study (1994) shows that in the 1980 s and early 1990 s social expenditure in a group of countries in the region did not amount to a significant proportion of their GDP, the variations in such expenditure were not anti-cyclical with respect to changes in GDP, and it did not have significantly progressive effects on distribution. Clearly, the prevailing political system has not used social policy to change the situation of marked inequality observed in most Latin American countries. This empirical result is also consistent with the theory proposed in this article. 


\section{VI}

\section{Conclusions}

The question which has been the guiding theme of the present study is whether a society can become developed even though it starts with a high degree of inequality and, in particular, whether a country can be competitive in the international economy regardless of its present degree of inequality.

If the initial conditions of an economy are a notable natural resource endowment and a high degree of inequality, private investment will be directed towards exploiting those resources and producing them in enclaves. With such initial conditions, it is unlikely that the investment will lead to the development of comparative and competitive advantages. Thus, international trade will not help to reduce the excess labour that the economy may have, nor will inequality be reduced through trade.

If there were any relation between trade and equity, it would be rather in the opposite direction: in order to develop comparative and competitive advantages, a country must have quite a low degree of inequality. The logic followed by investors would lead them to place their investments in countries with socio-political stability, which would depend on the degree of equity of society. Exports do not induce economic growth, as is usually claimed; exports are endogenous. It is investment which generates growth and higher productivity, so that the country increases in competitiveness. And the more intensive in their requirements for social order are the goods that a country exports, the greater will be the effect of equity on its net exports. The international competitiveness of a country depends on its degree of equity: that is the theory which has been developed in the present article.

When empirically tested, the theory shows an acceptable degree of consistency with the data for Latin America. One prediction of this theory is that the economic performance of countries depends on their initial degree of equity and factor endowment. At the beginning of the 1960s, Latin America started with pronounced inequality and an abundant endowment of natural resources and unskilled labour; South
Korea and Taiwan, in contrast, started with the opposite conditions: greater equity and an endowment of human capital. The evolution of our region and of those two Asian countries in terms of growth, equity and competitiveness has been as predicted by the theory: nowadays we talk about "Asian Tigers" but not "Latin American Tigers".

Another prediction of the theory which is in keeping with the actual trends displayed by the world economy is that long-term capital flows tend to go preferably to the more equalitarian countries. At the present time, there is greater world economic integration, especially in the financial field. Exchangerate controls have been abandoned and the capital markets have been globalized. According to a study by the Organization for Economic Co-operation and Development (OECD), world foreign direct investment flows have increased in recent decades at ut precedented rates, three to five times greater than the growth rate of international trade flows (Oman, 1996. p. 26), This indicates that countries (including those of the Third World) cannot be viewed as being different in terms of their capital endowments, since capital can now be considered as being intemationally mobile.

In short, the relative levels of productivity of countries (what we defined here as long-term com. petitiveness) depend on the distribution of investments among them; these investments depend on public investment and on the degree of socio-political stability of the recipient countries, which in turn depends on equity. Hence, competitiveness depends on equity. Since socio-political stability requires a certain degree of organization of society in order to maintain an acceptable level of equity, competitiveness is clearly not just a question of microeconomic or sectoral efficiency, nor is it merely a question of the macroeconomic balances: it is also a social question. Societies compete with each other to attract private investment in order to become competitive, and the factors in this competition include their degree of equity.

(Original: Spanish). 


\section{Bibliography}

Alesina, A. and R. Perotti (1993): Income Distribution, Political Instability, and Investment, Working Paper No. 4486, Cambridge, MA, National Bureau of Economic Research, Inc. (NBER), October.

Barro, R. (1990): Macroeconomics, New York, Wiley \& Sons Inc.

Bourguignon, F. and C. Morrisson (1989): External Trade and Income Distribution, Paris, Organization for Economic Cooperation and Development (OECD).

Deininger, K, and L. Squire (1996): A new data set meas. uring income inequality, The World Bank Economic Review, vol. 10, No. 3, Washington, D. C., World Bank.

ECLAC (Economic Commission for Latin America and the Caribbean) (1990): Changing Production Patterns with Social Equity, LC/G.1601-P, Santiago, Chile. United Nations publication, Sales No. E.90.II.G.6.

(1994): El gasto social en América Latina: un examen cuantitativo y cualitativo, "Cuadernos de la CEPAL" series, No. 73, LC/G.1854-P, Santiago, Chile. United Nations publication, Sales No. S.95.IIG.9.

(1995): Latin America and the Caribbean: Policies to improve linkages with the global economy,
LC/G.1800/Rev.1-P, Santiago, Chile. United Nations publication, Sales No. E.95.II.G.6.

El Comercio (1996): Lima, 3 January.

Figueroa, A. (1993): Crisis distributiva en el Perú, Lima, Catholic University of Peru, Fondo Editorial.

Hicks, J. (1989): A Market Theory of Money, Oxford, U.K, Clarendon Press.

IMF (International Monetary Fund) (1974); International Financial Statistics Yearbook 1974, Washington, D. C.

(1994): International Financial Statistics Yearbook 1994, Washington, D. C.

Krugman, P. (1995): The Age of Diminished Expectations, Cambridge, MA, The MIT Press.

Lucas, R. (1988): On the mechanics of economic development, Journal of Monetary Economics, vol. 22, No. 1, Amsterdam, Netherlands, North-Holland Publishing Company, July.

Oman, C. (1996): Desafios políticos de la globalización y regionalizacion, Lima, Friedrich Ebert Foundation (FEF).

Solow, R. (1990): The Labour Market as a Social Institution, Oxford, U. K., Basil Blackwell. 